\title{
ANALISIS TINGKAT KEPATUHAN WAJIB PAJAK DALAM MEMBAYAR PAJAK BUMI DAN BANGUNAN DI KANTOR PAJAK PRATAMA MANADO
}

\author{
Javier Sondakh \\ Jenny Morasa \\ Heince Wokas \\ Fakultas Ekonomi dan Bisnis Jurusan Akuntansi \\ Universitas Sam Ratulangi Manado \\ email : javi.sondakh@yahoo.com
}

\begin{abstract}
ABSTRAK
Sesuai dengan keputusan menteri keuangan falsafah pemajakan PBB No 34/PMK.03/2005 tentang pembagian hasil penerimaan pajak bumi dan bangunan antara pemerintah pusat dan pemerintah daerah bahwa hasil penerimaan Pajak Bumi dan Bangunan diarahkan untuk tujuan kepentingan masyarakat, maka hasil penerimaan PBB merupakan penerimaan Negara yang harus dibagi antara pemerintah pusat dengan pemerintah daerah. Tujuan penelitian ini adalah untuk mengetahui tingkat kepatuhan wajib pajak dalam Target dan Realisasi pembayaran Pajak Bumi dan Bangunan. Sumber data yang digunakan dalam penelitian ini adalah data sekunder yaitu data yang berasal dari Kantor Pelayuanan Pajak Pratama Manado. Hasil penelitian menunjukkan bahwa Penerimaan Pajak Bumi dan Bangunan dalam kurun waktu empat tahun dari tahun 2008-2011 terus mengalami peningkatan kecuali pada tahun 2009. Pada umumnya sebagian besar masyarakat sadar akan kewajibannya sebagai warga Indonesia yang baik dan mereka sadar bahwa pajak adalah bentuk partisipasi masyarakat dalam pembangunan daerah untuk lebih baik maju dan berkembang. Juga ada sebagian kecil masyarakat tidak menyadari akan kewajibannya sebagai wajib pajak PBB.
\end{abstract}

Kata kunci: kepatuhan wajib pajak, membayar PBB

\begin{abstract}
In accordance with the decision of the finance minister 34/PMK.03/2005 UN taxation philosophy about sharing property tax revenues between the central government and local governments that receive the proceeds of land and building tax is directed for the purpose of public interest, then the proceeds from the PBB constitutes acceptance of the State which must be shared between the central government and local governments. The purpose of this study was to determine the level of tax compliance in Target and Realization of Land and Building Tax payments. Sources of data used in this study is secondary data is data that comes from the Tax Office Primary service Manado. The results showed that the Land and Building Tax Revenue in theperiod of four years from 2008-2011 continued to increase except in the year 2009. In general, most people are aware of their obligations as citizens of Indonesia are good and they are aware that taxes are a form of public participation in local development to better developed and developing countries. Also there is a small community is not aware of its obligations as a taxpayer PBB.
\end{abstract}

Keyword: mandatory compliance tax, pay $P B B$ 


\section{PENDAHULUAN}

\section{Latar Belakang}

Pajak merupakan gejala sosial dan hanya terdapat dalam suatu masyarakat. Tanpa adanya masyarakat, tidak mungkin ada suatu pajak.Masyarakat yang dimaksud adalah masyarakat hukum. harus dibuat menjadi sadar pajak, masyarakat juga ditanamkan Tax Discipline yang kuat, didasari dengan kejujuran yang mantap. Namun demikian dalam pelaksanaan pemungutannya memerlukan landasan pertimbangan keadilan dan suatu kepastian hukum yang mengikat seluruh rakyat Indonesia. Hal ini ditegaskan dalam undang-undang dasar 1945 pasal 23A yang berbunyi "Pajak dan pungutan yang bersifat memaksa untuk keperluan Negara diatur dengan undang-undang". Untuk setiap jenis pajak selalu diatur dengan undang-undang tersendiri.

Wajib pajak adalah Wajib pajak dikatakan patuh apabila wajib pajak tersebut dapat memenuhi dan melaksanakan kewajiban perpajakan. Kewajiban tersebutdapat memenuhi dan melaksanakan kewajiban perpajakan. Kewajiban perpajakan harus dilaksanakan karena kewajiban merupakan suatu tanggung jawab yang harus dipenuhi oleh semua wajib pajak. Kepatuhan wajib pajak tersebut berupa : Tepat waktu membayar pajak dan membayar sesuai dengan waktu yang telah ditentukan . Pada prinsipnya kepatuhan perpajakan adalah tindakan wajib pajak dalam pemenuhan kewajiban perpajakannya sesuai dengan ketentuan peraturan perundang-undangan.

Predikat Wajib pajak patuh dalam arti disiplin dan taat, tidak sama dengan wajib pajak yang berpredikat pembayaran pajak dalam jumlah besar, tidak ada hubungan antara kepatuhan dengan jumlah nominal setoran pajak yang dibayar kepada kas Negara. Karena, pembayaran pajak terbesar sekalipun belum tentu memenuhi criteria sebagai wajib pajak patuh, meskipun memberikan kontribusi besar pada Negara. Jika masih memiliki tunggakan maupun keterlambatan penyetoran pajak maka tidak dapat diberi predikat wajib pajak patuh.

Indonesia menganut system pemungutan pajak Self Assessment yang artinya Suatu system pemungutan pajak yang memberikan kepercayaan kepada wajib pajak untuk menghitung, memperhitungkan sendiri pajak terutang dan kemudian melunasinya serta melaporkannya ke kantor pelayanan pajak tempat Wajib Pajak terdaftar (Hutagaol 2007:2).

Undang-undang yang mengatur pajak bumi dan bangunan adalah Undang-undang No.12 tahun 1985 sebagaimana telah diubah dengan undang-undang No.12 tahun 1994. Bumi dan bangunan memberikan keuntungan dan kedudukan sosial ekonomi yang lebih baik bagi orang atau badan yang mempunyai hak atasnya dan memperoleh manfaat dari padanya. Dasar pengenaan pajak dalam PBB adalah Nilai Jual Objek Pajak (NJOP). NJOP ditentukan berdasarkan harga pasar per wilayah dan ditetapkan setiap tahun oleh menteri keuangan.

\section{Tujuan Penelitian}

Tujuan yang ingin dicapai dalam penelitian ini adalah untuk mengetahui tingkat kepatuhan wajib pajak dalam Target dan Realisasi pembayaran Pajak Bumi dan Bangunan di Kantor Pajak Pratama Manado

\section{TINJAUAN PUSTAKA}

\section{Pengertian Akuntansi}

Hongren et al (2007:5) Akuntansi adalah sistem informasi yang mengukur akuntansi bisnis, mengolah , memproses informasi kedalam laporan-laporan dan menyampaikan hasilnya kepada pembuat keputusan.

American Institute of Certified Public Accounting (AICPA) dalam Balkaoui (2008:37) mendefinisikan akuntansi adalah seni pencatatan, penggolongan dan peringkasan transaksi dan kejadian yang bersifat keuangan dengan cara yang berdaya guna dan dalam bentuk satuan uang dan penginterprestasikan hasil tersebut. 


\section{Konsep Akuntansi Perpajakan}

Soemitro (2008:10) menyatakan Pada Prinsipnya Akuntansi Perpajakan menganut konsep-konsep akuntansi karena akumulasi transaksi selama masa suatu periode tertentu diselenggarakan dengan pencatatan teratur dalam proses pembukuan. Tujuan pembukuan yaitu mempermudah Wajib pajak dalam mengisi surat pemberitahuan Tahunan (SPT), mempermudah perhitungan besarnya penghasilan kena Pajak, Penyajian Informasi tentang posisi Finansia dan hasil usaha sebagai bahan analisis maupun pengambilan keputusan.

Hal-hal yang perlu diperhatikan mengenai konsep-konsep dasar akuntansi Perpajakan, yaitu :

a. Kesatuan Usaha (business entity)

b. Dasar-dasar pencatatan

c. Konsep periode waktu

d.Unit moneter

e. Transaksi

f. Kelangsungan Usaha (going concern)

g. Konsep Penandingan (Matching Concept)

\section{Pengertian Pajak}

Pajak merupakan pemindahan sumber daya dari sektor privat (perusahaan) ke sektor public, dari segi ekonomi. Pemindahan sumber daya tersebut akan mempengaruhi daya beli (purchasing power) atau kemampuan belanja (spending power) dari sektor privat. Agar tidak terjadi gangguan yang serius terhadap jalannya perusahaan, maka pemenuhan kewajiban perpajakan harus dikelola dengan baik (Suandy 2011:1). Bagi Negara, pajak adalah satu sumber penerimaan penting yang akan digunakan untuk membiayai pengeluaran Negara, baik pengeluaran rutin maupun pengeluaran pembangunan.

Definisi atau pengertian pajak menurut UU no 28 tahun 2009 tentang KUP pajak adalah kontribusi wajib pajak kepada negara yang terhutang oleh pribadi/badan yang bersifat memaksa berdasarkan UU, dengan tidak mendapatkan imbalan secara langsung dan digunakan untuk keperluan negara bagi sebesar -besarnya kemakmuran rakyat.

Pajak menurut Kamus Ekonomi (Sumadji, 2010:613) Tax adalah Suatu pembayaran yang dilakukan kepada pemerintah untuk membiayai pengeluaran yang dilakukan dalam hal menyelenggarakan jasa-jasa untuk kepentingan umum.

Unsur Pajak

\section{Unsur Pajak}

Pajak memiliki unsur-unsur yakni hal-hal yang membentuknya. Mardiasmo (2009:1) mengungkapkan unsur-unsur pajak terdiri dari:

1. Ada masyarakat

2. Ada Undang-undang

3. Ada pemungut pajak

4. Ada subjek pajak atau wajib pajak

\section{Fungsi Pajak}

Dasarnya fungsi pajak menurut Waluyo (2011:6) adalah sebagai sumber keuangan negara. Namun ada fungsi lainnya yang tidak kalah pentingnya yaitu pajak sebagai fungsi mengatur. Berikut adalah penjelasan untuk masingmasing fungsi tersebut :

\section{Fungsi sumber keuangan negara (budgetair)}

Fungsi sumber keuangan negara fungsi pajak untuk memasukkan uang ke kas negara atau sebagai sumber penerimaan negara dan digunakan untuk pengeluaran negara baik pengeluaran rutin maupun pengeluaran pembangunan.

2. Fungsi mengatur (regularend) 
Fungsi mengatur dimaksudkan sebagai usaha pemerintah untuk turut campur tangan dalam hal mengatur, mengubah susunan pendapatan dan kekayaan sektor swasta.

\section{Penggolongan Pajak}

Seperti yang diungkapkan dalam Waluyo (2011:12), terdapat pengelompokan pajak, yaitu :

\section{a. Menurut Golongannya}

Menurut golongannya pajak dibagi menjadi dua yaitu :

1. Pajak langsung

2. Pajak tidak langsung

\section{b. Pajak Menurut Sifatnya}

Menurut sifatnya pajak dibagi menjadi dua yaitu :

1. Pajak subjektif (bersifat perorangan)

2. Pajak objektif (bersifat kebendaan)

\section{c.Menurut lembaga pemungutannya}

Menurut lembaga pemungutannya pajak dibagi menjadi dua yaitu:

1. Pajak Negara (pajak pusat)

Pajak yang dipungut pemerintah pusat yang penyelenggaraannya dilaksanakan oleh departemen keuangan dan hasilnya akan digunakan untuk pembiayaan rumah tangga negara pada umumnya.

a. Pajak yang dipungut oleh Dirjen Pajak :

2. Pajak Daerah

Pajak-pajak yang dipungut oleh daerah seperti Propinsi, Kabupaten maupun Kota berdasarkan peraturan daerah masing-masing.

a. Pajak-pajak tingkat Propinsi:.

b. Pajak-pajak tingkat Kabupaten/Kota

\section{Wajib Pajak}

\section{Pengertian Wajib Pajak}

Undang-undang Republik Indonesia No.28 tahun 2009 menyatakan Wajib Pajak adalah orang Pribadi atau badan,meliputi membayar pajak,pemotong pajak,dan pemungut pajak,yang mempunyai hak dan kewajiban perpajakan sesuai dengan ketentuan peraturan perundang-undangan perpajakan daerah.

Markus (2009:25) mengungkapkan Wajib Pajak adalah Orang Pribadi yang menurut ketentuan peraturan perundang-undangan perpajakan ditententukan untuk melakukan kewajiban perpajakan , termasuk pemungut pajak atau pemotong pajak Tertentu.

Wajib Pajak adalah Orang pribadi atau Badan, meliputi pembayaran pajak,pemotong pajak, dan pemungut pajak,yang mempunyai hak dan kewajiban perpajakan sesuai dengan ketentan peraturan perundang-undangan perpajakan. (Mardiasmo 2008:21)

\section{Pentingnya Kepatuhan Wajib Pajak}

Masalah kepatuhan Wajib Pajak adalah masalah yang penting diseluruh dunia,baik bagi Negara maju maupun Negara berkembang. Karena jika Wajib Pajak tidak patuh maka akan menimbulkan keinginan untuk melakukan penghindaran, pengluhan dan penyelundupan pajak . Yang pada akhirnya tindakan tersebut akan menyebabkan penerimaan pajak Negara berkurang.

Wajib Pajak patuh adalah Wajib Pajak yang sadar Pajak, Paham hak dan kewajiban perpajakannya dan diharapkan peduli pajak yaitu melaksanakan kewajiban perpajakan dengan benar dan paham akan hal perpajakannya.

Penyebab Wajib Pajak tidak patuh bervariasi salah satunya adalah fitrannya penghasilan yang diperoleh Wajib Pajak utama ditujukan untuk memenuhi kebutuhan hidupnya. 


\section{Pajak Bumi dan Bangunan}

Dasar Hukum Pajak Bumi dan Bangunan (PBB) adalah undang-undang No.12 tahun 1985 sebagaimana telah diubah dengan undang-undang No.12 tahun 1994.

\section{Pengertian Pajak Bumi dan Bangunan}

Mardiasmo, (2009:311) menyatakan Pajak Bumi dan Bangunan memiliki arti:

Bumi adalah Permukaan bumi da tubuh bumi yang ada dibawahnya. Permukaan bumi meliputi tanah dan perairan pedalaman (termasuk rawa-rawa,tambak,perairan) serta laut Wilayah Republik Indonesia. Bangunan adalah Konstruksi teknik yang ditanam atau diletakan secara tetap pada tanah atau perairan.Undang-undang Republik Indonesia No.28 Tahun 2009 menyatakan Pajak Bumi dan Bangunan adalah Pajak atas bumi dan bangunan yang dimiliki,dikuasai, atau dimanfaatkan oleh orang pribadi atau badan,kecuali kawasan yang digunakan untuk kegiatan usaha perkebunan,perhutanan,dan pertambangan.

Surat Pemberitahuan Objek Pajak (SPOP) adalah surat yang digunakan oleh wajib pajak untuk melaporkan data objek menurut ketentuan undang-undang Pajak Bumi dan Bangunan.

Surat Pemberitahuan Pajak terutang (SPPT) adalah surat yang digunakan oleh Direktorat Jenderal pajak untuk memberitahukan besarnya pajak terutang kepada wajib pajak. Direktorat jenderal Pajak menerbitkan SPPT (Surat pemberitahuan Pajak terutang) berdasarkan SPOP (Surat Pemberitahuan Objek Pajak) Wajib Pajak .

Nilai Jual Objek Pajak

Nilai Jual Objek Pajak (NJOP) adalah harga rata-rata yang diperoleh dari transaksi jual-beli secara wajar, dan bila mana tidak terdapat transaksi jual beli, Nilai Jual Objek Pajak ditentukan melalui perbandingan harga dengan objek lain yang sejenis, atau nilai perolehan baru, atau Nilai Jual Objek Pajak pengganti.

\section{Cara Menghitung Pajak}

Besarnya pajak terutang dihitung dengan cara mengkalikan tarif pajak dengan NJKP.

Pajak Bumi dan Bangunan = Tarif Pajak x NJKP

$$
=0,5 \% \times \text { Presentase NJKP } \times \text { (NJOP-NJOPTKP) }
$$

(Undang-undang no.12 tahun 1985 sebagaimana telah diubah dengan undang-undang no.12 tahun 1994.)

\section{Penelitian Terdahulu}

\section{Tabel 1 Penelitian Terdahulu}

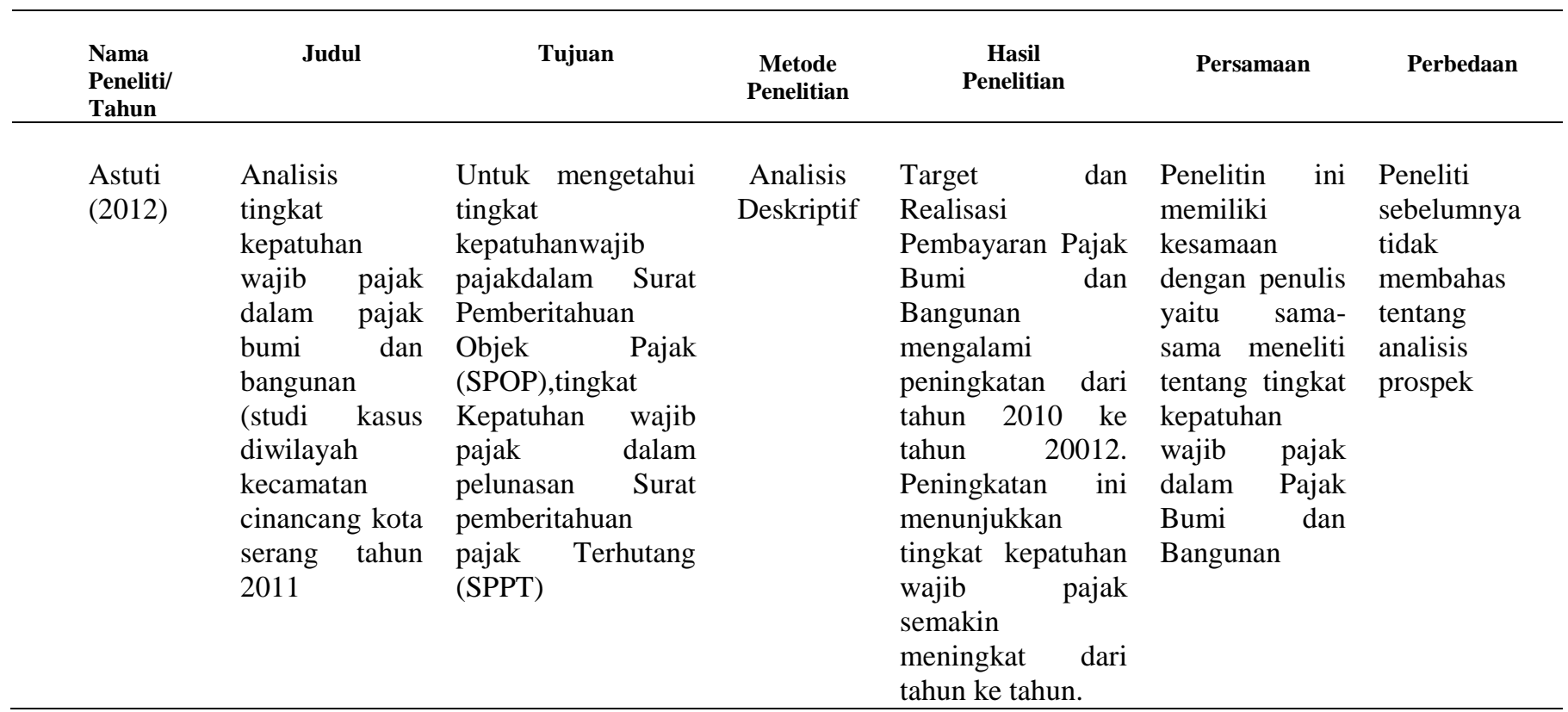




\begin{tabular}{|c|c|c|c|c|c|c|}
\hline $\begin{array}{l}\text { Koentarto } \\
(2006)\end{array}$ & $\begin{array}{l}\text { Analisis } \\
\text { Faktor-Faktor } \\
\text { yang } \\
\text { Mempengaruhi } \\
\text { Kepatuhan } \\
\text { Masyarakat } \\
\text { Dalam } \\
\text { Melakuka } \\
\text { Pembayaran } \\
\text { (Studi Kasus } \\
\text { pada Ke } \\
\text { Kecamatan } \\
\text { Arust Selatan } \\
\text { Kabupaten } \\
\text { Kotawaringin } \\
\text { Barat) }\end{array}$ & 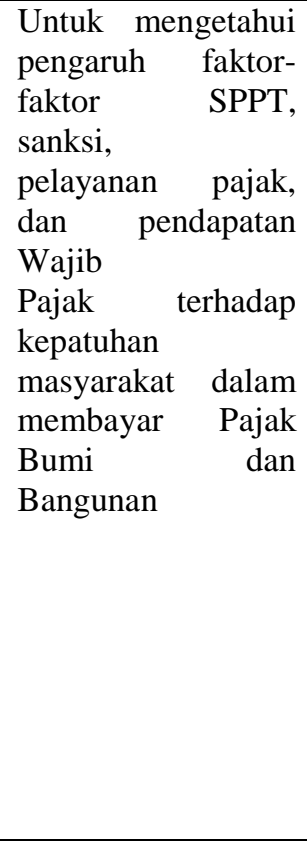 & $\begin{array}{l}\text { Analisi } \\
\text { Faktor }\end{array}$ & $\begin{array}{l}\text { Dari hasil analisis } \\
\text { faktor terbukti ada } \\
4 \\
\text { faktor yang } \\
\text { mempengaruhi } \\
\text { kepatuhan } \\
\text { masyarakat } \\
\text { dalam melakukan } \\
\text { pembayaran Pajak } \\
\text { Bumi dan } \\
\text { Bangunan dan 15 } \\
\text { item variabel } \\
\text { pendukung yang } \\
\text { signifikan, yaitu } \\
\text { Surat } \\
\text { Pemberitahuan } \\
\text { Pajak Terutang } \\
\text { (SPPT), pelayanan } \\
\text { pajak, pendapatan } \\
\text { Wajib Pajak dan } \\
\text { sanksi }\end{array}$ & $\begin{array}{l}\text { Sama-sama } \\
\text { melakukan } \\
\text { penelitian } \\
\text { tentang tingkat } \\
\text { kepatuhan } \\
\text { wajib pajak } \\
\text { dalam Pajak } \\
\text { Bumi dan } \\
\text { Bangunan }\end{array}$ & $\begin{array}{l}\text { Peneliti } \\
\text { sebelumnya } \\
\text { tidak } \\
\text { membahas } \\
\text { tentang } \\
\text { analisis } \\
\text { prospek dan } \\
\text { menggunakan } \\
\text { analisis } \\
\text { faktor }\end{array}$ \\
\hline
\end{tabular}

\section{METODE PENELITIAN}

\section{Jenis Penelitian}

Jenis penelian ini adalah penelitian deskriptif untuk memberikan gambaran cara sistematis dan akurat mengenai fakta, sifat dari hubungan antar fenomena yang diteliti pada objek penelitian. Gambaran yang sistematis dan akurat diperoleh dengan mengumpulkan, mengklasifikasikan data sehingga akan memberikan hasil yang konkrit pada permasalahan dan kemudian dilaksanakan analisis sehingga dapat ditarik kesimpulan.

\section{Tempat dan Waktu Penelitian}

Penelitian ini dilakukan di Kantor Pelayanan Pajak Pratama Manado yang berada di Jalan 17 Agustus Manado, Sulawesi Utara. Periode waktu penelitian dimulai dari akhir bulan Agustus sampai dengan September 2013.

\section{Prosedur Penelitian}

Penulis melakukan kajian awal dengan melakukan studi literatur baik studi kepustakaan maupun membaca melalui internet. Kemudian melakukan pengidentifikasian tentang masalah, merumuskannya, menetapkan tujuan/ manfaat penelitian, kemudian membatasi masalah ke lingkup yang disesuaikan dengan penelitian saat ini. Perancangan dan persiapan survai pada objek penelitian yang telah ditentukan, kemudian pengumpulan data baik primer maupun sekunder. Melakukan pengolahan data, membahasnya kemudian menarik kesimpulan dan memberikan saran-saran guna melengkapi penelitian.

\section{Metode Pengumpulan Data Jenis dan Sumber Data}

Data dapat dibedakan menjadi dua jenis (Kuncoro 2006: 24) yaitu :

1. Data kualitatif merupakan data yang tidak dapat diukur dalam skala numerik atau data yang disajikan secara deskriptif atau yang berbentuk uraian

2. Data kuantitatif merupakan data yang disajikan dalam bentuk skala numerik (angka-angka), namun dalam statistik semua data harus dalam bentuk angka, maka data kualitatif umumnya dikuantitatifkan agar dapat diproses 
Jenis data yang digunakan dalam penelitian ini berupa data kualitatif yang berbentuk uraian

\section{Sumber Data dalam penelitian ini adalah}

\section{Data Primer}

Data primer dalam penelitian ini diperoleh dari hasil wawancara dan pengamatan dengan pihak-pihak yang terkait. Dalam hal ini Wajib Pajak.

Data Sekunder

Merupakan data dari sumber tertulis, baik dari buku-buku literatur maupun dokumen - dokumen serta laporan-laporan yang diperoleh dari Kantor Pajak Pratama Manado.

Teknik Pengumpulan Data

Beberapa teknik pengumpulan data sebagai berikut :

a. Wawancara atau Interview

b. Observasi

c. Dokumentasi

\section{Metode Analisa Data}

Metode analisa data yang digunakan dalam penelitian ini adalah analisa deskriptif kuantitatif. Analisa deskriptif kuantitatif digunakan untuk menjelaskan maupun menyajikan data yang diperoleh dari instansi dengan memberikan gambaran umum menurut apa adanya sesuai dengan kenyataan yang ada pada saat melakukan penelitian. Dan untuk peramalan pada tahun 20012-2018 digunakan analisis trend.

\section{HASIL PENELITIAN DAN PEMBAHASAN}

\section{Gambaran Umum Kantor Pelayanan Pajak Pratama Manado}

Kantor Pelayanan Pajak berdiri pada tahun 1959, yang merupakan pecahan dari Kantor Pelayanan Pajak Makassar, dimana pada waktu itu menggunakan istilah Kantor Inspeksi Keuangan. Untuk daerah Sulawesi Utara meliputi Sulut dan Sultengyang dalam perkembangan selanjutnya pada tahun 1969 diubah menjadi Kantor Inspeksi Pajak dengan wilayah kerja meliputi Sulut dan Sulteng. Kemudian pada tanggal 1 Desember 2008, Kantor Pelayanan Pajak Manado berubah namanya menjadi Kantor Pelayanan Pajak Pratama Manado yang wilayah kerjanya meliputi Kota Manado dan Kota Tomohon.

Dalam menjalankan tugas dan fungsi tersebut KPP Pratama Manado berorientasi pada visi dan misi berikut, yaitu:

Visi : Menjadi institusi pemerintah yang menyelenggarakan sistem administrasi perpajakan modern yang efektif, efisien dan dipercaya masyarakat dengan integritas dan profesionalitas yang tinggi."

Misi : Menghimpun penerimaan pajak negara berdasarkan Undang-undang Perpajakan yang mampu mewujudkan kemandirian pembiayaan Anggaran Pendapatan dan Belanja Negara melalui sistem administrasi perpajakan yang efektif dan efisien.

\section{Hasil Penelitian}

Berikut ini data laporan Target dan Realisasi Penerimaan PBB di KPP Pratama Manado dalam 4 (empat) tahun terakhir, yaitu tahun 2008-2011 dapat dilihat pada tabel 2 sebagai berikut:

Tabel 2Target dan Realisasi Penerimaan PBB di KPP Pratama Manado Tahun 2008-2011

\begin{tabular}{lccc}
\hline \multicolumn{2}{c}{ Tahun/Uraian } & Target (Rp) & Realisasi (Rp) \\
\hline \multirow{2}{*}{2008} & SKB & $13,324,000,000$ & $12,723,814,000$ \\
& APBN & $42,541,360,000$ & $42,989,661,000$ \\
\multirow{2}{*}{2009} & SKB & $15,443,476,000$ & $14,209,528,000$ \\
& APBN & $41,010,216,000$ & $41,939,281,000$ \\
\multirow{2}{*}{2010} & SKB & $16,712,282,750$ & $20,648,085,920$ \\
& APBN & $42,774,419,630$ & $52,760,216,020$ \\
& SKB & $22,833,780,000$ & $20,249,027,870$ \\
& APBN & $57,049,584,510$ & $54,668,108,610$ \\
\hline
\end{tabular}

Sumber : KPP Pratama Manado, 2013 
Keterangan

- $\quad$ Des 2008 s.d Sekarang Kantor Pelayanan PBB Manado menjadi KPP pratama Manado wilayah kerja kota Manado dan kota Tomohon

- $\quad$ SKB (Surat Ketetapan Bersama) = Sektor Pedesaaan dan Perkotaan APBN (Anggaran Penerimaan Belanja Negara) = Jumlah PBB termasuk sektor SKB dan sektor P3 (Perkebunan, Perhutanan, Pertambangan).

Data diatas dapat kita lihat dalam tabel 2 dimana Penerimaan Pajak Bumi dan Bangunan di KPP Pratama Manado mengalami peningkatan setiap tahunnya kecuali pada tahun 2009, target yang diberikan lebih minimal, sehingga realisasi juga tidak tercapai maksimal seperti tahun lainnya.

Tabel 3 Penerimaan PBB Berdasarkan Target dan Realisasi di KPP Pratama Manado Tahun 2008-2011

\begin{tabular}{cccc}
\hline Tahun Anggaran & Target (Rp) & Realisasi (Rp) & Persentase (\%) \\
\hline 2008 & $42,541,360,000$ & $42,989,661,000$ & $101.05 \%$ \\
2009 & $41,010,216,000$ & $41,939,281,000$ & $102.27 \%$ \\
2010 & $42,774,419,630$ & $52,760,216,020$ & $123.35 \%$ \\
2011 & $57,049,584,510$ & $54,668,108,610$ & $95.83 \%$ \\
\hline
\end{tabular}

Sumber : KPP Pratama Manado, 2013

Berdasarkan tabel 3 dapat dilihat bahwa pada tahun 2009 Target dan Realisasi mengalami penurunan, dimana tahun 2008 target $\mathrm{Rp}$ 42,541,360,000. sedangkan $2009 \mathrm{Rp}$ 41,010,216,000. pada

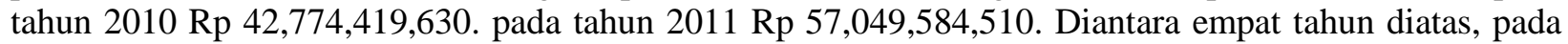
tahun 2009 adalah tahun target yang paling rendah dibandingkan dengan tahun 2008, 2010, 2011. Dalam tabel 4.2. dapat dilihat bahwa realisasi penerimaan Pajak Bumi dan bangunan setiap tahunnya di KPP Pratama Manado mengalami peningkatan sehingga dapat penulis simpulkan bahwa tingkat kepatuhan masyarakat sebagai wajib pajak PBB semakin meningkat.

Faktor yang mempengaruhi WP PBB dalam membayar PBB dan usaha usaha yang dilakukan fiskus dalam meningkatkan kepatuhan WP PBB dalam membayar PBB di Lingkungan KPP Pratama Manado adalah tata cara pembayaran di KPP Pratama Manado atau pelaksanaan pembayaran PBB yang mempermudah WP PBB melaksanakan kewajiban perpajakannya sehingga kepatuhan dan kesadaran WP PBB yang selama ini belum sepenuhnya ber jalan dengan sempurna akan dapat diminimalisir dengan segala kemudahan yang diberikan.

\section{Prospek Penerimaan Pajak Bumi dan bangunan di di KPP Pratama Manado}

Peramalan jumlah Pajak Bumi dan bangunan di KPP Pratama Manado pada tahun-tahun yang akan datang, penulis menggunakan ramalan (trend). Untuk meramalkan berapa besar Pajak Bumi dan bangunan di KPP Pratama Manado dengan menggunakan metode statistik estimating line regresi linier sederhana yaitu $\mathrm{Y}=\mathrm{a}+\mathrm{bx}$. Umtuk meramalkan $\mathrm{Y}$, maka a dan $\mathrm{b}$ harus di ketahui terlebih dahulu, dimana a adalah intercept yaitu jarak dari titik asal ke titik perpotongan antara garis regresi dengan sumbu tegak, sedangkan $\mathrm{b}$ adalah koefisien arah (slope) atau koefisien regresi

Tabel 4 Analisis Penerimaan Pajak Bumi dan Bangunan di KPP Pratama Manado Tahun 2008-

\begin{tabular}{|c|c|c|c|c|}
\hline Tahun & $\left(\mathbf{X}_{\mathbf{i}}\right)$ & Jumlah PBB (Rp) $\left(\mathbf{Y}_{\mathrm{i}}\right)$ & $\left(\mathbf{X}_{\mathrm{i}}\right)^{2}$ & $\left(\mathbf{X}_{\mathbf{i}} \mathbf{Y}_{\mathbf{i}}\right)(\mathbf{R p})$ \\
\hline 2008 & 0 & $42,989,661,000$ & 0 & 0 \\
\hline 2009 & 1 & $41,939,281,000$ & 1 & 41.939 .281 .000 \\
\hline 2010 & 2 & $52,760,216,020$ & 4 & 105.520 .432 .040 \\
\hline 2011 & 3 & $54,668,108,610$ & 9 & 164.004 .325 .830 \\
\hline Jumlah & 6 & $192,357,266,630$ & 14 & 396.392 .980 .870 \\
\hline
\end{tabular}

Sesuai dengan persamaan normal Supranto (2009:112) adalah sebagai berikut : 


$$
\begin{aligned}
& \sum \mathrm{Y} \quad=\text { na }+\mathrm{b} \Sigma \mathrm{Xi} \\
& \sum \mathrm{Xi} \mathrm{Yi}=\Sigma \mathrm{xa}+\mathrm{b} \sum \mathrm{Xi}^{2} \\
& \text { Rp 192.357.266.630 } \quad=4 a+6 b \quad 1 \times 3 \\
& \text { Rp 396.392.980.870 } \quad=6 \mathrm{a}+14 \mathrm{~b} \quad 11 \times 2 \\
& \begin{array}{ll}
\text { Rp 577.071.799.890 } & =12 \mathrm{a}+18 \mathrm{~b} \\
\operatorname{Rp} 792.785 .961 .740 & =12 \mathrm{a}+28 \mathrm{~b} .
\end{array} \\
& \mathrm{Rp}-215.714 .161 .850=-10 \mathrm{~b} \\
& 10 \mathrm{~b}=\operatorname{Rp} 215.714 .161 .850 \\
& \mathrm{~b}=\operatorname{Rp} 21.571 .416 .185
\end{aligned}
$$
menghasilkan

Koefisien b dalam hal ini dinamakan koefisien regresi kita subtitusikan b ke dalam 1 maka akan

$$
\begin{aligned}
& 4 \mathrm{a}+6 \mathrm{~b} \quad=192.357 .266 .630 \\
& 4 a+6(21.571 .416 .185) \quad=192.357 .266 .630 \\
& 4 \mathrm{a}+129.428 .497 .110 \quad=192.357 .266 .630 \\
& 4 \mathrm{a} \quad \quad=192.357 .266 .630-129.428 .497 .110 \\
& 4 \mathrm{a} \quad \quad=62.928 .769 .520 \\
& \mathrm{a}=\operatorname{Rp} 15.732 .192 .380
\end{aligned}
$$

model regresi liniernya menjadi

$$
\mathrm{Y}=\mathrm{Rp} 15.732 .192 .380+\operatorname{Rp} 21.571 .416 .185(\mathrm{X})
$$

Diketahuinya model regresi, maka dapatlah kita menaksir jumlah penerimaan Pajak Bumi dan Bangunan di KPP Pratama Manado yang akan datang. Misalnya untuk menaksir jumlah pajak pada tahun 2015 ( $X=7$ ) dengan mengambil tahun 2008 sebagai tahun dasar $(X=0)$ di perkirakan sebagai berikut :

$$
\begin{aligned}
& \text { Tahun } 2015(\mathrm{X}=7) \\
& \mathrm{Y}=\mathrm{Rp} 15.732 .192 .380+21.571 .416 .185 \\
& \mathrm{Y}=\mathrm{Rp} 15.732 .192 .380+21.571 .416 .185(7) \\
& \mathrm{Y}=\mathrm{Rp} \quad 166.732 .105 .675
\end{aligned}
$$

Jadi pada tahun 2015 jumlah Pajak Bumi dan Bangunan di KPP Pratama Manado di perkirakan Rp 166.732.105.675 apabila faktor-faktor lainnya tetap

Model persamaan garis linier dapat diramalkan (forcesting trend) penerimaan pajak Bumi dan Bangunan di KPP Pratama Manado Tahun 2008 sampai 2018, dapat di lihat dalam tabel berikut :

Tabel 5 Prospek Penerimaan Pajak Bumi dan Bangunan di KPP Pratama Manado Tahun 2008-2018

\begin{tabular}{ccc}
\hline \hline Tahun & $\mathbf{X}_{\mathbf{i}}$ & $\mathbf{Y}_{\mathbf{I}}(\mathbf{R p})$ \\
\hline \hline 2008 & 0 & $42,989,661,000$ \\
2009 & 1 & $41,939,281,000$ \\
2010 & 2 & $52,760,216,020$ \\
2011 & 3 & $54,668,108,610$ \\
2012 & 4 & 78.660 .961 .900 \\
2013 & 5 & $94,393,154,280$ \\
2014 & 6 & $145,160,689,490$ \\
2015 & 7 & 166.732 .105 .675 \\
2016 & 8 & $172,571,329,480$. \\
2017 & 9 & $194,142,745,665$ \\
2018 & 10 & $215,714,161,850$ \\
\hline \hline
\end{tabular}

Sumber Data Olahan Hasil Penelitian, 20013

Trend penerimaan PBB di KPP Pratama Manado tahun 2008-2018 dapat dilihat pada gambar berikut. 


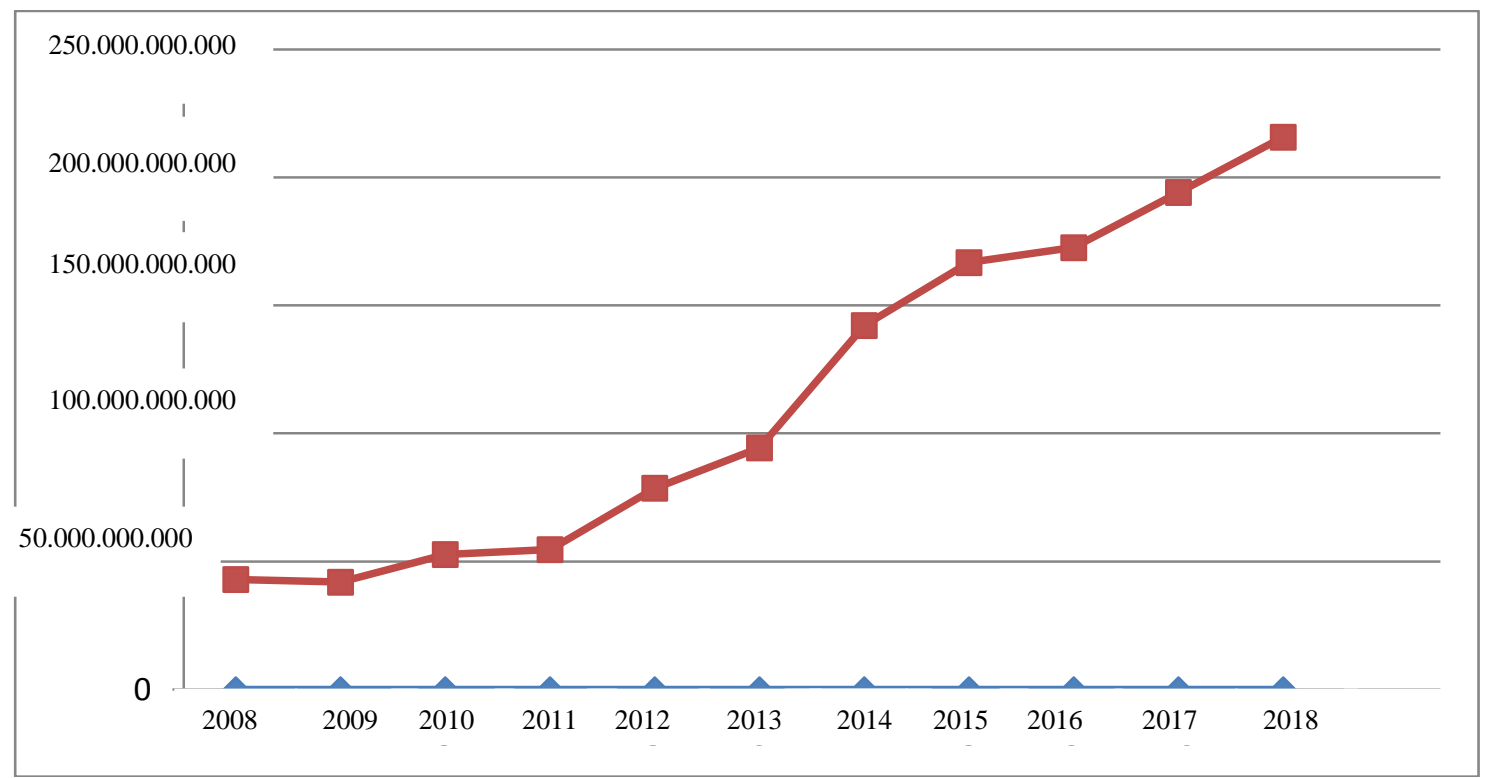

Gambar Trend Penerimaan PBB di KPP Pratama Manado tahun 2008-2018

Berdasarkan gambar dapat dilihat bahwa trend penerimaan Pajak Bumi dan Bangunan di KPP Pratama Manado tahun 2009 sebesar Rp 42.989.661.000, tahun 2009 sebesar Rp 41.939.281.000, tahun 2010 sebesar Rp 52.760.216.120, tahun 2011 sebes Rp 54.668.961.900, tahun 2012 sebesar Rp 78.660.961.900, sedangkan pada tahun 2015 diprediksi sebesar Rp 166.732.105.675 dan tahun 2018 sebesar Rp 215. 714. 161.850.

\section{Kesimpulan}

\section{PENUTUP}

1. Penerimaan Pajak Bumi dan Bangunan dalam kurun waktu empat tahun dari tahun 2008-2011 terus mengalami peningkatan kecuali pada tahun 2009. Namun, dari target yang di berikan kepada KPP Pratama Manado sudah terealisasikan secara efektif.

2. Pada umumnya sebagian besar masyarakat sadar akan kewajibannya sebagai warga Indonesia yang baik dan mereka sadar bahwa pajak adalah bentuk partisipasi masyarakat dalam pembangunan daerah untuk lebih baik maju dan berkembang.

3. Ada sebagian kecil masyarakat tidak menyadari akan kewajibannya sebagai wajib pajak PBB. Masyarakat menganggap pembangunan daerah bukan merupakan tanggung jawab mereka dan mereka tidak menyadari bahwa fasilitas sarana danprasarana yang mereka manfaatkan adalah hasil dari penerimaan PBB. Sehingga masyarakat merasa tidak perlu membayar PBB.

4. Prospek penerimaan Pajak Bumi dan Bangunan di KPP Pratama Manado tahun 2009 sebesar Rp 42.989.661.000, tahun 2009 sebesar Rp 41.939.281.000, tahun 2010 sebesar Rp 52.760.216.120, tahun 2011 sebes Rp 54.668.961.900, tahun 2012 sebesar Rp 78.660.961.900, sedangkan pada tahun 2015 diprediksi sebesar Rp 166.732.105.675 dan tahun 2018 sebesar Rp 215. 714. 161.850 .

\section{Saran}

1. Tata cara pembayaran sudah bagus, jadi harus tetap dipertahankan dan lebih ditingkatkan seperti kolektor atau petugas pemungut pajak harus lebih aktif dalam memungut PBB. 
2. Bagi wajib pajak yang masih tidak sadar akan kewajibannya dalam membayar PBB sebaiknya harus melaksanakan pembayaran $\mathrm{PBB}$ guna untuk memajukan dan mengembangkan pembangunan daerah yang bersangkutan.

3. Hendaknya fiskus dan instansi terkait harus meningkatkan pelayanannya dan lebih mendekatkan diri kepada masyarakat sehingga masyarakat merasa bahwa pajak bukan merupakan suatu beban tetapi kewajiban yang memang harus dipenuhi.

4. Wajib Pajak tetap harus berperan aktif sesuai dengan sistem perpajakannya yang berlaku yakni sistem self assessmentyaitu wajib pajak harus mengisi sendiri SPOP untuk mendaftarkan tanah atau bangunannya sebagai objek pajak.

\section{DAFTAR PUSTAKA}

Astuti, Puji. 2012. Analisisi Tingkat Kepatuhan Wajib Pajak dalam Pajak Bumi dan Bangunan (PBB) Studi kasus di Wilayah Kecamatan Cinancang Kota Serang Tahun 2011. Skripsi. Universitas Islam Negeri Maulana Malik Ibrahim .Serang. Www.gopdfs.com/jurnal-kepatuhan wajib pajak. Diakses 2 Mei 2013.

Balkaoui, Ahmed Riahi. 2008. Teori Akuntansi Edisi Pertama. Salemba Empat. Jakarta.

Hutagaol, John.2007. Perpajakan. Graha Ilmu. Jakarta

Hongren.,Horizon.,Bamber 2007. Accounting, Fifth Edition, Prentice Hall International. Jakarta

Koentarto, Ilham 2006 Faktor-Faktor yang Mempengaruhi Kepatuhan Masyarakat Dalam Melakuka

Pembayaran (Studi Kasus pada Kecamatan Arust Selatan Kabupaten Kotawaringin Barat). Skripsi Universitas Brawijaya. Malang www.jobscholarship.com/...jurnal- kepatuhan-wajib pajak bumi dan bangunan. Diakses 2 Mei 2013

Kuncoro, Mudrajad. 2006. Metode Riset Untuk Bisnis dan Ekonomi. Erlangga. Jakarta.

Mardiasmo.2008. Perpajakan, Edisi Revisi 2008. Andi. Jakarta.

Mardiasmo. 2009. Perpajakan, Edisi Revisi 2009. Andi. Jakarta.

Markus, Muda. 2009.Perpajakan Indonesia.Gramedia Pustaka Utama. Jakarta.

Republik Indonesia. Direktorat Jenderal Pajak.Undang-Undang No.28 Tahun 2007 Tentang Ketentuan Umum dan Tatacara Perpajakan. Jakarta

Jakarta

Suandy.2009. Pajak Daerah dan Retribusi Daerah.Grafindo Persada. Jakarta.

Supranto. 2009. The Power of Statistics. Salemba Empat. Jakarta

Sumadji. 2010. Akuntansi Perpajakan. LPMB/STEI. Ciledug

Soemitro.2008.Akuntansi Pajak, Edisi Revisi. Gramedia Widia Sarana Indonesia. Jakarta.

Waluyo.2011. Perpajakan Indonesia. Edisi 10 buku 2.Salemba Empat. Jakarta. 